\title{
Effects of the type of biomass and ashing temperature on the properties of solid fuel ashes
}

\author{
Jiří Horák, Lenka Kuboňová*, Milan Dej, Vendula Laciok, Šárka Tomšejová, František Hopan, \\ Kamil Krpec, Jan Koloničný \\ VŠB-Technical University of Ostrava, Energy Research Center, 17. listopadu 2172/ 15, 70800 Ostrava - Poruba, Czech \\ Republic \\ "Corresponding author: e-mail: lenka.kubonova@vsb.cz
}

\begin{abstract}
Ashes were prepared by annealing selected types of solid fuels (biomass: corn cobs, sunflower husks, olive pomace, hay pellets and rice husks; coal: lignite and bituminous; and alternative fuel: paper sludge) at different temperatures $\left(550^{\circ} \mathrm{C}, 815^{\circ} \mathrm{C}\right.$ and $\left.975^{\circ} \mathrm{C}\right)$. Based on X-ray fluorescence spectra, the slagging/fouling indexes were used to study the effects of the type of ash and the ashing temperature on the ash fouling and slagging properties. Slagging indexes were compared with the ash fusion temperatures. Ash fusion temperatures were measured by a LECO AF-700. The lowest deformation temperature (below $1000^{\circ} \mathrm{C}$ ) was seen for the ashes prepared from hay pellets and corn cobs. On the other hand, the deformation temperature exceeded $1500^{\circ} \mathrm{C}$ for ashes prepared from paper sludge, sunflower husks and rice husks. By calculating the different slagging/fouling indexes, all the ashes exhibited slagging/fouling problems of varying degrees.
\end{abstract}

Keywords: biomass, ashing temperature, ash fusion temperature, slagging index, fouling index.

\section{INTRODUCTION}

Recycling and reusing biomass ashes are essential from an economic and environmental perspective ${ }^{1}$. In addition, residual ash forms slag inside boilers, which degrades the burning process, decreases heat transfer and causes high-temperature corrosion and erosion problems, all of which reduce the lifetimes of equipment ${ }^{2,3,4}$. For the operation of various types of solid fuel furnaces, it is important to know the melting point of the ashes that are present. In practice, this temperature determines how high combustion temperatures in furnaces can be, so as not to cause failures of the combustion devices (sealing the gaps in gratings with slag, creating deposits on fireplace walls) $)^{5}$. One method for burning fuels with low ash-melting temperatures is to use additives ${ }^{6}$.

The melting point is the temperature at which all components contained in an ash are melted. This process takes place over a wide temperature interval ( $200 \mathrm{~K}$ or more) during which the ash state changes. The compositions of the ash and the ambient atmosphere in a combustion chamber influence the ash melting temperature. Ashes mainly contain $\mathrm{SiO}_{2}, \mathrm{Al}_{2} \mathrm{O}_{3}, \mathrm{Fe}_{2} \mathrm{O}_{3}, \mathrm{FeO}, \mathrm{CaO}, \mathrm{MgO}$, $\mathrm{Na}_{2} \mathrm{O}, \mathrm{K}_{2} \mathrm{O}, \mathrm{SO}_{3}, \mathrm{TiO}_{2}$ and $\mathrm{P}_{2} \mathrm{O}_{5}$. In addition to these oxides, ashes can contain different elements $(\mathrm{Zn}, \mathrm{Pb}$, $\mathrm{As}, \mathrm{Ge}, \mathrm{Be}, \mathrm{Ni}, \mathrm{Cd}$, etc. $)^{5}$. The presence of alkali metals and alkaline earth metals influences the formation of hard and ash deposits. Alkali metals decrease the ash melting point, while alkaline earth metals increase the melting point. $\mathrm{SiO}_{2}$ and $\mathrm{Al}_{2} \mathrm{O}_{3}$ also influence the melting temperature by increasing it. However, $\mathrm{FeO}$, $\mathrm{Fe}_{2} \mathrm{O}_{3}, \mathrm{TiO}_{2}, \mathrm{CaO}, \mathrm{MgO}, \mathrm{Na}_{2} \mathrm{O}$ and $\mathrm{K}_{2} \mathrm{O}$ decrease the melting temperature ${ }^{5}$.

To estimate the probabilities of deposit and slag forming in combustion units, there are slagging and fouling indexes. These indexes are based on the elemental composition of biomass ash and its combustion behaviour and their equations are mainly based on values obtained from coal. The different slagging and fouling indexes are the silica content $\left(\mathrm{SiO}_{2}\right)^{7}$, silica-alumina ratio $(\mathrm{S} / \mathrm{A})^{8}$, chlorine content of the fuel ${ }^{7,9}$, basic-to-acidic oxides ratio
$(\mathrm{B} / \mathrm{A})^{7}$, fouling index $(\mathrm{Fu})^{7}$, Babcock index $(\mathrm{Rs})^{7}$, slag viscosity index $(\mathrm{Sr})^{7,}$, , iron-calcium ratio $(\mathrm{I} / \mathrm{C})^{8}$, total alkalis $(\mathrm{TA})^{8}$, bed agglomeration index $(\mathrm{BAI})^{7}$ and ash fusibility index (AFI) ${ }^{7}$.

A summary of the slagging and fouling indexes is in Table 1, and their calculations are in Table 2.

For biomass fuels (especially fuels that do not contain wood), massive slagging of the heat exchange surfaces of the boilers during combustion occurs. In our study, common biomass fuels were selected, and their ash fusibilities were studied and compared with those of coal fuels. The aim was to examine the properties of individual biomass fuels to assess the suitability of biomass fuels for use in boilers.

Ashes prepared at different temperatures $\left(550^{\circ} \mathrm{C}, 815^{\circ} \mathrm{C}\right.$ and $975^{\circ} \mathrm{C}$ ) from selected types of solid fuels (biomass: corn cobs, sunflower husks, olive pomace, hay pellets, and rice husks; coal: lignite and bituminous; and alternative fuel: paper sludge) were analysed to determine the influence of the ashing temperature and the effect of the biomass type on the composition and properties of the ashes. Compositional analysis was performed together with calculations of the indexes. The effect of the ashing temperature on the properties of biomass ashes has been previously studied ${ }^{2,3,4,10}$.

\section{Experimental Section}

For the production of ashes, six types of solid biofuels were selected (corn cobs, sunflower husks, olive pomace, hay pellets and rice husks), one representing alternative fuels (dried sludge from paper production, paper sludge) and two types of fossil fuels (lignite and bituminous coal) and are listed in Table 3. Rice husks have been studied by different authors ${ }^{10-13}$, corn cobs by Yao $^{10}, 14,15$, sunflower husks by Rizvi ${ }^{16}$, and wastes from olives by several authors ${ }^{1,8,17}$. The designations and temperatures of the ashes are summarized in Table 3. The temperature for ash preparation $\left(550^{\circ} \mathrm{C}\right)$ was selected according to the EN ISO $18122^{18}$ standard for solid biofuels, a temperature of $815^{\circ} \mathrm{C}$ was selected according to the ISO $1171^{19}$ 
Table 1. Slagging and fouling indexes

\begin{tabular}{|c|c|c|c|}
\hline Index & Range & Slagging and fouling inclination & Reference \\
\hline \multirow[t]{3}{*}{$\mathrm{SiO}_{2}(\%)$} & $<20$ & Low & 7 \\
\hline & $20-25$ & Medium & \\
\hline & $>25$ & High & \\
\hline \multirow[t]{2}{*}{ Silica-alumina ratio (S/A) } & $<0.31,>3$ & Low & 8 \\
\hline & $0.3-3$ & High & \\
\hline \multirow[t]{4}{*}{$\mathrm{Cl}(\%)$} & $<0.2$ & Low & 7,9 \\
\hline & $0.2-0.3$ & Medium & \\
\hline & $0.3-0.5$ & High & \\
\hline & $>0.5$ & Extremely high & \\
\hline \multirow[t]{4}{*}{ Base-acid ratio (B/A) } & $<0.5$ & Low & 7 \\
\hline & $0.5-1$ & Medium & \\
\hline & $1.0-1.75$ & High & \\
\hline & $>1.75$ & Extremely high & \\
\hline \multirow{3}{*}{ Fouling index (Fu) } & $<0.6$ & Low & 7 \\
\hline & $0.6-40$ & Medium & \\
\hline & $>40$ & High & \\
\hline \multirow[t]{3}{*}{ Babcock index (Rs) } & $<0.6$ & Low & 7 \\
\hline & $0.6-2$ & Medium & \\
\hline & $2.0-2.6$ & High & \\
\hline \multirow[t]{3}{*}{ Slag viscosity index (Sr) } & $>72$ & Low & 7,9 \\
\hline & $65-72$ & Medium & \\
\hline & $<65$ & High & \\
\hline \multirow[t]{2}{*}{ Iron-calcium ratio (I/C) } & $<0.31,>3$ & Low & 8 \\
\hline & $0.3-3$ & High & \\
\hline \multirow[t]{3}{*}{ Total alkalis (TA) } & $<0.3$ & Low & 8 \\
\hline & $0.3<\mathrm{TA}<0.4$ & Medium & \\
\hline & $>0.4$ & High & \\
\hline Bed agglomeration index (BAI) & $<0.15$ & High & 7 \\
\hline \multirow[t]{4}{*}{ Ash fusibility index (AFI) } & $>1342$ & Low & 7 \\
\hline & $1232-1342$ & Medium & \\
\hline & $1052-1232$ & High & \\
\hline & $<1052$ & Extremely high & \\
\hline \multirow[t]{3}{*}{$\mathrm{DT}\left({ }^{\circ} \mathrm{C}\right)$} & $>1100$ & Low & 7 \\
\hline & $900-1100$ & Medium & \\
\hline & $<900$ & High & \\
\hline
\end{tabular}

Table 2. The calculations for the slagging and fouling indexes

\begin{tabular}{|c|c|}
\hline Index & Calculation \\
\hline Silica-slumina ratio $(\mathrm{S} / \mathrm{A})$ & $\mathrm{S} / \mathrm{A}=\frac{\mathrm{SiO}_{2}}{\mathrm{Al}_{2} \mathrm{O}_{3}}$ \\
\hline Base-acid ratio $(\mathrm{B} / \mathrm{A})$ & $\mathrm{B} / \mathrm{A}=\frac{\left(\mathrm{Fe}_{2} \mathrm{O}_{3}+\mathrm{CaO}+\mathrm{MgO}+\mathrm{K}_{2} \mathrm{O}+\mathrm{Na}_{2} \mathrm{O}+\mathrm{P}_{2} \mathrm{O}_{5}\right)}{\left(\mathrm{SiO}_{2}+\mathrm{TiO}_{2}+\mathrm{Al}_{2} \mathrm{O}_{3}\right)}$ \\
\hline Fouling index (Fu) & $\mathrm{Fu}=(\mathrm{B} / \mathrm{A}) \cdot\left(\mathrm{Na}_{2} \mathrm{O}+\mathrm{K}_{2} \mathrm{O}\right)$ \\
\hline Babcock index (Rs) & $\mathrm{Rs}=(\mathrm{B} / \mathrm{A}) \cdot \mathrm{S}^{\mathrm{d}}$ \\
\hline Slag viscosity index (Sr) & $\mathrm{Sr}=\frac{\mathrm{SiO}_{2}}{\mathrm{SiO}_{2}+\mathrm{Fe}_{2} \mathrm{O}_{3}+\mathrm{CaO}+\mathrm{MgO}} \cdot 100$ \\
\hline Iron-calcium ratio $(\mathrm{I} / \mathrm{C})$ & $\mathrm{I} / \mathrm{C}=\frac{\mathrm{Fe}_{2} \mathrm{O}_{3}}{\mathrm{CaO}}$ \\
\hline Total alkalis (TA) & $\mathrm{TA}=\mathrm{Na}_{2} \mathrm{O}+\mathrm{K}_{2} \mathrm{O}$ \\
\hline Bed agglomeration index (BAI) & $\mathrm{BAI}=\frac{\mathrm{Fe}_{2} \mathrm{O}_{3}}{\mathrm{Na}_{2} \mathrm{O}+\mathrm{K}_{2} \mathrm{O}}$ \\
\hline Ash fusibility index (AFI) & $\mathrm{AFI}=\frac{4 \cdot \mathrm{IDT}+\mathrm{HT}}{5}$ \\
\hline
\end{tabular}

standard for solid mineral fuels, and a temperature of $975^{\circ} \mathrm{C}$ was the temperature used for the determination of the major elements by the XRF method.
The ashes were prepared in a temperature-controlled annealing furnace. The temperature rise to the desired value was gradual to avoid crossing the target temperature and the temperature was held at $250^{\circ} \mathrm{C}$ (for 1 hour) to 
Table 3. Sample designations and preparation temperatures of the ashes

\begin{tabular}{|l|c|}
\hline Sample name & $\begin{array}{c}\text { Designation and preparation } \\
\text { temperature of the ash }\end{array}$ \\
\hline Paper sludge ash & PSA_550 \\
\hline Corn cob ash & CCA_550 \\
\hline Sunflower husk ash & SHA_550 \\
\hline Hay pellet ash & HPA_550 \\
\hline Olive pomace ash & OPA_550 \\
\hline Olive pomace ash & OPA_815 \\
\hline Olive pomace ash & OPA_975 \\
\hline Rice husk ash & RHA_550 \\
\hline Rice husk ash & RHA_815 \\
\hline Rice husk ash & RHA_975 \\
\hline Lignite ash & LA_815 \\
\hline Lignite ash & LA_975 \\
\hline Bituminous coal ash & BCA_815 \\
\hline Bituminous coal ash & BCA_975 \\
\hline
\end{tabular}

degas the samples. The required temperature for ashing was held for at least 5 hours.

\section{Analytical methods}

The prepared ashes were analysed by the following methods:

- The determination of the major elements in the ashes was performed by elemental analysis of the solid ashes by the XRFS method.

- The determination of chloride was performed by titration and ion chromatography. For low concentrations of chlorides, the titration method was performed according to ČSN EN 196- $2^{20}$. If the chloride concentration exceeded the determination value of this method, the ion chromatography according to US EPA Method 1011B was used.

- The determination of the ash fusion temperatures was performed by a LECO AF-700 instrument which was used to record the height and width of up to 6 bodies at one time to determine changes in the shape of bodies.

\section{RESULTS AND DISCUSSION}

\section{Ash fusion temperatures}

The resulting values for the deformation temperature (DT), the sphere temperature (ST), the hemisphere temperature $(\mathrm{HT})$ and the flow temperature $(\mathrm{FT})$ in reductive and oxidative atmospheres are shown in Table 4. DT is the temperature at which the first signs of rounding, due to melting, of the tip or edges of the test piece occur; ST is the temperature at which the height of a pyramid or truncated cone-shaped test piece is equal to the width of the base; HT is the temperature at which the test piece approximately forms a hemisphere, and FT is the temperature at which the ash melt spreads over the supporting tile in a layer.

For biomass, it has been suggested that DT should be used as an evaluation inde $\mathrm{x}^{\mathbf{2 1}}$. The DTs under oxidative and reductive atmospheres for all analysed ash samples are shown in Fig. 1. In general, the ash fusion temperatures increased with increasing ashing temperature. The lowest temperatures are seen for the ashes produced from hay pellets and corn cobs, for which the DTs are below $1000^{\circ} \mathrm{C}$. This could be a problem for fluidized bed or gasification systems that operate below $1000^{\circ} \mathrm{C}$. In the case of corn cobs, the low fusion temperature reflects its low calcium concentration and high alkali concentration, as shown below ${ }^{8}$. On the other hand, for ashes made from paper sludge, sunflower husks and rice husks, the DT exceeds $1500^{\circ} \mathrm{C}$. Paper sludge has the highest DT, which can be explained by its high silica and calcium contents together with a low alkali content, as shown below ${ }^{8}$.

The differences among the individual fusion temperatures (DT, ST, HT and FT) of the coal ash samples prepared at $815^{\circ} \mathrm{C}$ and $975^{\circ} \mathrm{C}$ are small and within the reproducibility tolerance of the applied method $( \pm 40 \mathrm{~K})$. The differences among the individual fusion tempera-

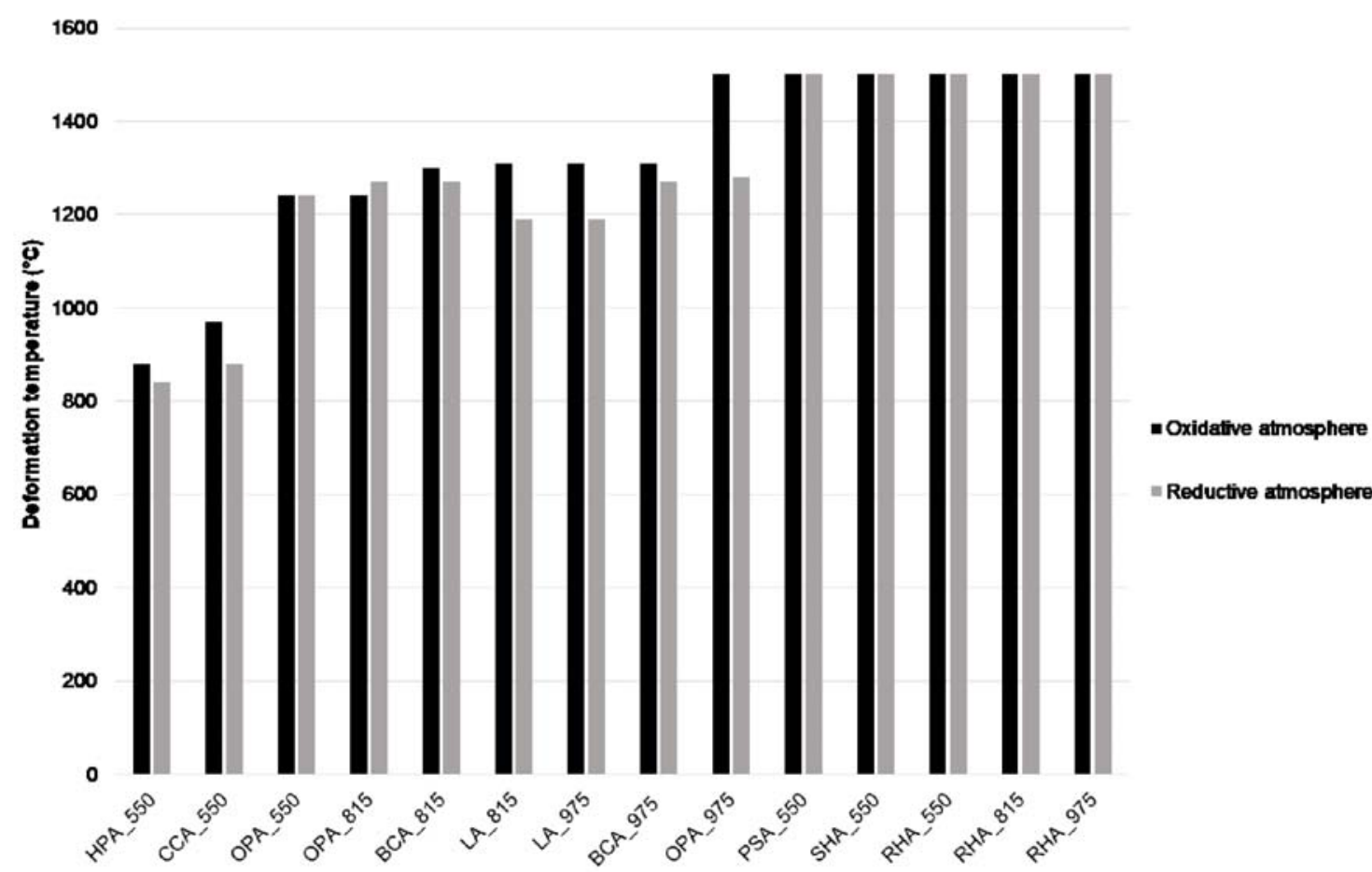

Figure 1. Deformation temperatures in oxidative and reductive atmospheres for biomass and coal ashes 
Table 4. Determination of ash fusion temperatures

\begin{tabular}{|c|c|c|c|c|c|c|c|c|c|}
\hline \multirow{2}{*}{$\begin{array}{l}\text { Sample of } \\
\text { ash }\end{array}$} & \multirow{2}{*}{ 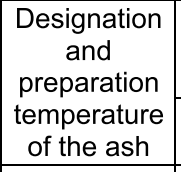 } & $\begin{array}{c}\text { Deformation } \\
\text { temperature } \\
\text { DT }\left[{ }^{\circ} \mathrm{C}\right] \\
\end{array}$ & $\begin{array}{c}\text { Sphere } \\
\text { temperature } \\
\text { ST }\left[{ }^{\circ} \mathrm{C}\right]\end{array}$ & $\begin{array}{c}\text { Hemisphere } \\
\text { temperature } \\
\text { HT }\left[{ }^{\circ} \mathrm{C}\right]\end{array}$ & $\begin{array}{c}\text { Flow } \\
\text { temperature } \\
\text { FT }\left[{ }^{\circ} \mathrm{C}\right] \\
\end{array}$ & \begin{tabular}{|c|} 
Deformation \\
temperature \\
DT $\left[{ }^{\circ} \mathrm{C}\right]$
\end{tabular} & \begin{tabular}{|c|} 
Sphere \\
temperature \\
ST $\left[{ }^{\circ} \mathrm{C}\right]$ \\
\end{tabular} & $\begin{array}{c}\text { Hemisphere } \\
\text { temperature } \\
\text { HT }\left[{ }^{\circ} \mathrm{C}\right]\end{array}$ & $\begin{array}{c}\text { Flow } \\
\text { temperature } \\
\text { FT }\left[{ }^{\circ} \mathrm{C}\right] \\
\end{array}$ \\
\hline & & $\begin{array}{c}\text { (reductive } \\
\text { atm.) }\end{array}$ & $\begin{array}{c}\text { (reductive } \\
\text { atm.) }\end{array}$ & $\begin{array}{c}\text { (reductive } \\
\text { atm.) }\end{array}$ & $\begin{array}{c}\text { (reductive } \\
\text { atm.) }\end{array}$ & $\begin{array}{c}\text { (oxidative } \\
\text { atm.) }\end{array}$ & $\begin{array}{c}\text { (oxidative } \\
\text { atm.) }\end{array}$ & $\begin{array}{c}\text { (oxidative } \\
\text { atm.) }\end{array}$ & $\begin{array}{c}\text { (oxidative } \\
\text { atm.) }\end{array}$ \\
\hline $\begin{array}{l}\text { Paper } \\
\text { sludge ash }\end{array}$ & PSA_550 & $>1500$ & $>1500$ & $>1500$ & $>1500$ & $>1500$ & $>1500$ & $>1500$ & $>1500$ \\
\hline $\begin{array}{l}\text { Corn cob } \\
\text { ash }\end{array}$ & CCA_550 & 880 & 900 & 970 & 1080 & 970 & 1000 & 1030 & 1100 \\
\hline $\begin{array}{l}\text { Sunflower } \\
\text { husk ash }\end{array}$ & SHA_550 & $>1500$ & $>1500$ & $>1500$ & $>1500$ & $>1500$ & $>1500$ & $>1500$ & $>1500$ \\
\hline $\begin{array}{l}\text { Hay pellet } \\
\text { ash }\end{array}$ & HPA_550 & 840 & 1020 & 1160 & 1300 & 880 & 970 & 1110 & 1260 \\
\hline $\begin{array}{l}\text { Olive } \\
\text { pomace } \\
\text { ash }\end{array}$ & OPA_550 & 1240 & 1250 & 1260 & 1330 & 1240 & 1270 & 1290 & 1330 \\
\hline $\begin{array}{l}\text { Olive } \\
\text { pomace } \\
\text { ash }\end{array}$ & OPA_815 & 1270 & 1320 & 1370 & 1400 & 1240 & 1280 & 1300 & 1460 \\
\hline $\begin{array}{l}\text { Olive } \\
\text { pomace } \\
\text { ash }\end{array}$ & OPA_975 & 1280 & 1310 & 1360 & 1410 & $>1500$ & $>1500$ & $>1500$ & $>1500$ \\
\hline $\begin{array}{l}\text { Rice husk } \\
\text { ash }\end{array}$ & RHA_550 & $>1500$ & $>1500$ & $>1500$ & $>1500$ & $>1500$ & $>1500$ & $>1500$ & $>1500$ \\
\hline $\begin{array}{l}\text { Rice husk } \\
\text { ash }\end{array}$ & RHA_815 & $>1500$ & $>1500$ & $>1500$ & $>1500$ & $>1500$ & $>1500$ & $>1500$ & $>1500$ \\
\hline $\begin{array}{l}\text { Rice husk } \\
\text { ash }\end{array}$ & RHA_975 & $>1500$ & $>1500$ & $>1500$ & $>1500$ & $>1500$ & $>1500$ & $>1500$ & $>1500$ \\
\hline Lignite ash & LA_815 & 1190 & 1270 & 1300 & 1360 & 1310 & 1320 & 1330 & 1350 \\
\hline Lignite ash & LA_975 & 1190 & 1240 & 1250 & 1330 & 1310 & 1320 & 1330 & 1350 \\
\hline $\begin{array}{l}\text { Bituminous } \\
\text { coal ash }\end{array}$ & BCA_815 & 1270 & 1300 & 1340 & 1380 & 1300 & 1310 & 1340 & 1380 \\
\hline $\begin{array}{l}\text { Bituminous } \\
\text { coal ash }\end{array}$ & BCA_975 & 1270 & 1300 & 1320 & 1370 & 1310 & 1320 & 1340 & 1390 \\
\hline
\end{tabular}

Note: DT: deformation temperature, ST: sphere temperature, HT: hemisphere temperature, FT: flow temperature ${ }^{22,23}$

tures for the olive pomace ashes prepared at different temperatures are within the range of $40-100 \mathrm{~K}$ under a reductive atmosphere, and it is not possible to distinguish between them due to the fusibility temperatures being $>1500^{\circ} \mathrm{C}$ for rice husk ash.

Significant differences among sequential fusion temperatures at the ash preparation temperature of $550^{\circ} \mathrm{C}$ can be observed for the hay pellet ash, which indicates a slow fouling rate inside the boilers.

\section{Major element and chloride concentrations in the ashes}

The oxides in biomass ashes can be divided into acidic oxides $\left(\mathrm{SiO}_{2}, \mathrm{Al}_{2} \mathrm{O}_{3}, \mathrm{SO}_{3}\right.$, etc. $)$ and basic oxides $\left(\mathrm{K}_{2} \mathrm{O}\right.$, $\mathrm{CaO}, \mathrm{MgO}, \mathrm{Na}_{2} \mathrm{O}, \mathrm{Fe}_{2} \mathrm{O}_{3}, \mathrm{P}_{2} \mathrm{O}_{5}$, etc.). The concentrations of the major elements and chlorides are shown in Table 5, Figs. 2 and 3.

As presented by Vassilev ${ }^{24}$ and in agreement with our study, a high concentration of $\mathrm{SiO}_{2}$ is characteristic of rice husks, whereas it is extremely low in sunflower husks. Of the samples, rice husks and corn cobs typically have the lowest content of $\mathrm{CaO}$, whereas paper sludge characteristically has the highest content of $\mathrm{CaO}$ due to the naturally high content of $\mathrm{CaO}$ in $\operatorname{wood}^{8}$. An extremely high concentration of $\mathrm{K}_{2} \mathrm{O}$ is characteristic of sunflower waste and corn cobs; in contrast, an extremely low content of $\mathrm{K}_{2} \mathrm{O}$ is seen in paper sludge. The highest concentration of $\mathrm{MgO}$ is typically seen in sunflower husks, whereas the lowest content of $\mathrm{MgO}$ is characteristically seen in rice husks. An extremely low content of $\mathrm{P}_{2} \mathrm{O}_{5}$ is typical for rice husks and paper sludge. The lowest value of $\mathrm{Al}_{2} \mathrm{O}_{3}$ is characteristically seen in sunflower husks and rice husks. An extremely low concentration of $\mathrm{SO}_{3}$ is typical for rice husks and paper sludge. The lowest content of $\mathrm{Fe}_{2} \mathrm{O}_{3}$ is characteristically seen in rice husks. An extremely low content of $\mathrm{Na}_{2} \mathrm{O}$ is typical for rice husks and paper sludge ${ }^{24}$.

Table 5. Concentrations of the major elements and chlorides in the ashes

\begin{tabular}{|c|c|c|c|c|c|c|c|c|c|c|c|c|c|c|c|c|}
\hline \multirow{2}{*}{\multicolumn{3}{|c|}{ Parameter }} & $\begin{array}{l}\text { Paper } \\
\text { sludge } \\
\text { ash }\end{array}$ & $\begin{array}{c}\text { Corn cob } \\
\text { ash }\end{array}$ & $\begin{array}{c}\text { Sunflow } \\
\text { er husk } \\
\text { ash }\end{array}$ & $\begin{array}{c}\text { Hay } \\
\text { pellet } \\
\text { ash }\end{array}$ & $\begin{array}{c}\text { Olive } \\
\text { pomace } \\
\text { ash }\end{array}$ & $\begin{array}{c}\text { Olive } \\
\text { pomace } \\
\text { ash }\end{array}$ & $\begin{array}{c}\text { Olive } \\
\text { pomace } \\
\text { ash }\end{array}$ & $\begin{array}{c}\text { Rice } \\
\text { husk ash }\end{array}$ & $\begin{array}{c}\text { Rice } \\
\text { husk ash }\end{array}$ & $\begin{array}{c}\text { Rice } \\
\text { husk } \\
\text { ash }\end{array}$ & $\begin{array}{l}\text { Lignite } \\
\text { ash }\end{array}$ & $\begin{array}{l}\text { Lignite } \\
\text { ash }\end{array}$ & $\begin{array}{c}\text { Bitumino } \\
\text { us coal } \\
\text { ash }\end{array}$ & $\begin{array}{c}\text { Bitumino } \\
\text { us coal } \\
\text { ash }\end{array}$ \\
\hline & & & PSA_550 & CCA_550 & SHA_550 & HPA_550 & OPA_550 & OPA_815 & OPA_975 & RHA_550 & RHA_815 & RHA_975 & LA_815 & LA_975 & BCA_815 & BCA_975 \\
\hline \multirow{5}{*}{$\begin{array}{l}\text { D } \\
\frac{0}{0} \\
\text { 음 } \\
\frac{}{0}\end{array}$} & $\mathrm{Na}_{2} \mathrm{O}$ & wt $\%$ & 0.36 & 5.90 & 4.60 & 2.20 & 5.00 & 4.00 & 3.80 & $<0.03$ & $<0.03$ & 0.46 & 1.94 & 1.20 & 1.13 & 1.05 \\
\hline & $\mathrm{MgO}$ & $w t \%$ & 3.47 & 7.00 & 12.70 & 3.09 & 3.89 & 5.60 & 5.78 & 0.37 & 0.16 & 0.41 & 2.75 & 3.24 & 2.53 & 2.45 \\
\hline & $\mathrm{Al}_{2} \mathrm{O}_{3}$ & $w t \%$ & 3.09 & 1.10 & 0.76 & 2.04 & 2.63 & 4.11 & 4.33 & 0.14 & 0.12 & 0.23 & 22.20 & 24.60 & 27.80 & 27.30 \\
\hline & $\mathrm{SiO}_{2}$ & $w t \%$ & 11.50 & 11.90 & 0.16 & 50.90 & 6.93 & 16.20 & 17.10 & 91.60 & 94.50 & 93.30 & 31.70 & 34.30 & 45.60 & 44.80 \\
\hline & $\mathrm{P}_{2} \mathrm{O}_{5}$ & $w t \%$ & 0.09 & 4.50 & 3.80 & 6.50 & 2.89 & 4.17 & 4.25 & 0.49 & 0.32 & 0.70 & 0.10 & 0.20 & 0.35 & 0.38 \\
\hline \multirow{6}{*}{ 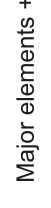 } & $\mathrm{SO}_{3}$ & wt $\%$ & 0.19 & 2.98 & 8.50 & 2.73 & 3.53 & 7.72 & 6.78 & 0.48 & 0.42 & 1.19 & 9.00 & 4.52 & 5.30 & 4.67 \\
\hline & $\mathrm{CaO}$ & $w t \%$ & 44.50 & 1.55 & 11.00 & 4.97 & 19.00 & 40.40 & 44.70 & 0.76 & 0.62 & 0.82 & 7.74 & 8.47 & 6.46 & 6.55 \\
\hline & $\mathrm{TiO}_{2}$ & $w t \%$ & 0.14 & 0.09 & 0.01 & 0.09 & 0.12 & 0.24 & 0.27 & 0.01 & 0.03 & 0.01 & 1.61 & 1.71 & 1.06 & 1.10 \\
\hline & $\mathrm{MnO}$ & wt $\%$ & 0.02 & 0.06 & 0.03 & 0.18 & 0.05 & 0.01 & 0.11 & 0.16 & 0.15 & 0.20 & 0.10 & 0.11 & 0.07 & 0.07 \\
\hline & $\mathrm{Fe}_{2} \mathrm{O}_{3}$ & $w t \%$ & 0.40 & 0.55 & 0.11 & 0.75 & 1.70 & 3.75 & 4.14 & 0.04 & 0.05 & 0.07 & 14.20 & 14.90 & 5.91 & 5.71 \\
\hline & $\mathrm{Cl}^{-}$ & $w t \%$ & 0.04 & 4.04 & 1.33 & 0.41 & 3.50 & 0.06 & 0.01 & 0.10 & 0.01 & $<0.01$ & 0.01 & 0.02 & 0.02 & 0.01 \\
\hline
\end{tabular}




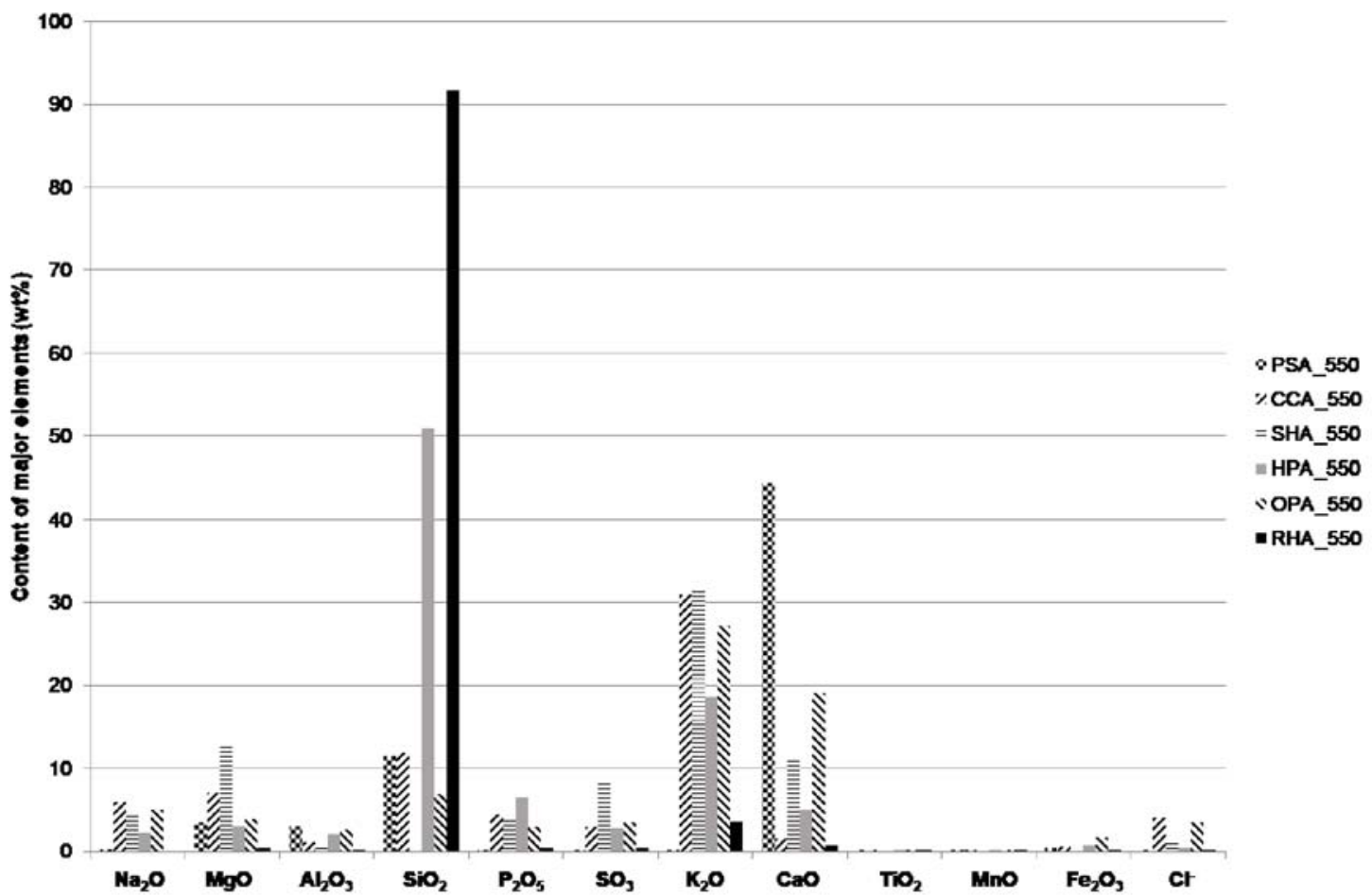

Figure 2. Contents of the major elements and chlorides for biomass ashes prepared at $550^{\circ} \mathrm{C}$

The presence of $\mathrm{Al}_{2} \mathrm{O}_{3}, \mathrm{MgO}, \mathrm{CaO}, \mathrm{Fe}_{2} \mathrm{O}_{3}$ and $\mathrm{SiO}_{2}$ in ash may increase the melting point, while the presence of $\mathrm{P}_{2} \mathrm{O}_{5}, \mathrm{Na}_{2} \mathrm{O}$ and $\mathrm{K}_{2} \mathrm{O}$ may decrease the melting point ${ }^{11}{ }^{11}, 25$. Thus, $\mathrm{SiO}_{2}, \mathrm{Al}_{2} \mathrm{O}_{3}$ and $\mathrm{CaO}$ may increase the melting point in the case of paper sludge ash and olive pomace ash. High amounts of $\mathrm{P}_{2} \mathrm{O}_{5}, \mathrm{Na}_{2} \mathrm{O}$ and $\mathrm{K}_{2} \mathrm{O}$ may decrease the melting point of corn cob ash. Ashes prepared from corn cobs and sunflower husks at $550^{\circ} \mathrm{C}$ have high amounts of potassium, which enables them to be easily sintered. A low melting temperature is observed for the corn cob ash, which is consistent with its high potassium content. High melting temperatures are seen for the paper sludge ash and rice husk ash, which is in agreement with their low potassium contents. For the other ashes, their melting temperatures cannot be expressed as a function of their potassium contents ${ }^{\mathbf{1 6}}$. Alkali metals can easily evaporate at high temperatures when in the form of inorganic salts, such as chlorides, oxides and sulfates ${ }^{11,21}$. Alkalis are known to produce molten salt mixtures via vaporization, condensation and secondary reactions ${ }^{8}$. The enrichment of potassium, sulfur and chlorine in ash is very harmful because of the risk of corrosion ${ }^{24,26}$. The corn cob ash has a higher chlorine content than other ashes. The higher concentrations of $\mathrm{Si}$ and $\mathrm{Al}$ in the hay pellet ash can trap alkali halides ( $\mathrm{KCl}$ as analysed by XRD, not shown) via the formation

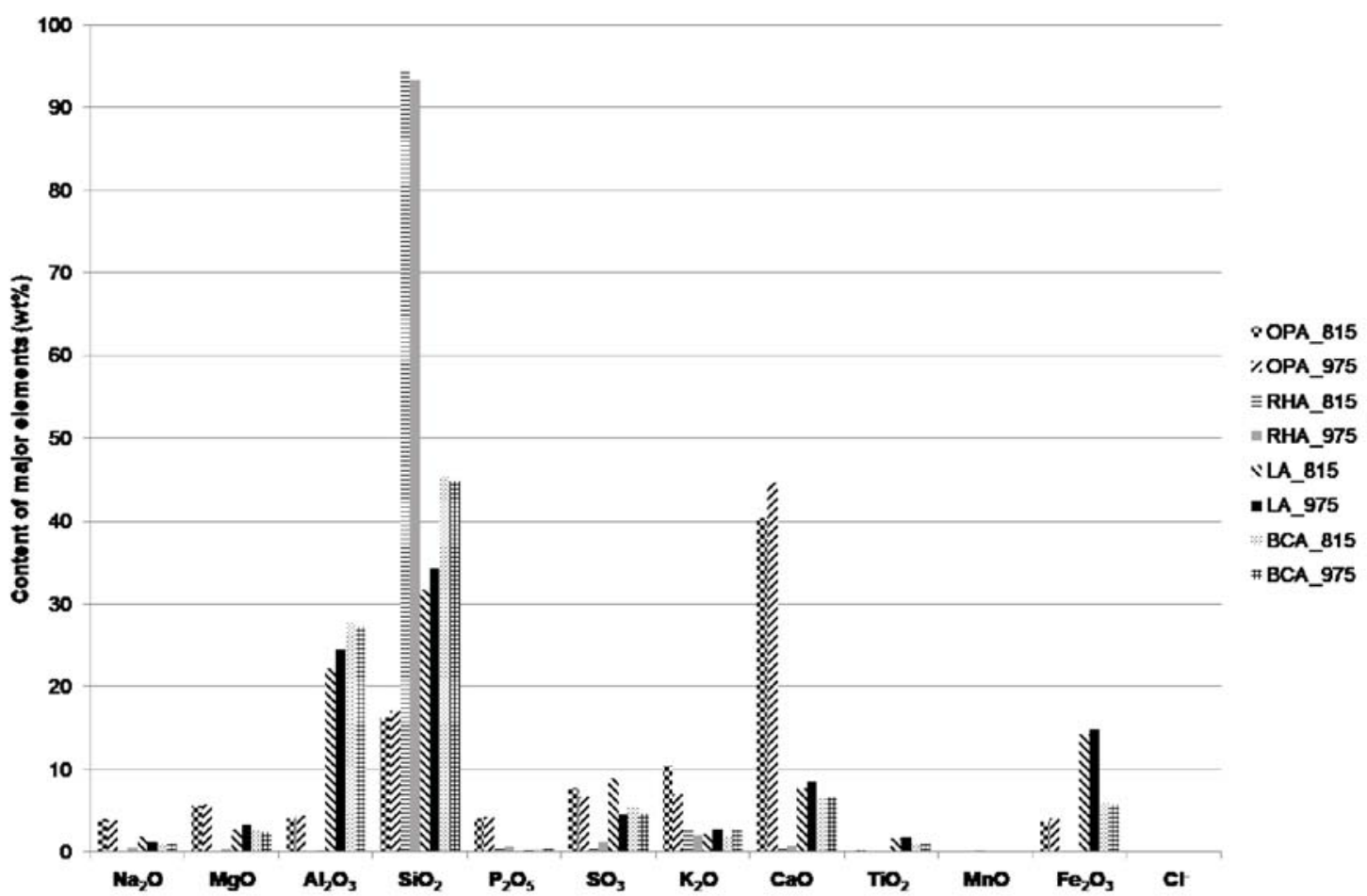

Figure 3. Contents of the major elements and chlorides for biomass and coal ashes prepared at $815^{\circ} \mathrm{C}$ and $975^{\circ} \mathrm{C}$ 
of silicates and aluminosilicates and promote formation of deposits on the hot surfaces in boilers ${ }^{2}$.

Lignite and bituminous coal are dominated by $\mathrm{SiO}_{2}-\mathrm{Al}_{2} \mathrm{O}_{3}$, which is common for many hard coals ${ }^{27}$. The lignite ash contained a large amount of $\mathrm{Fe}_{2} \mathrm{O}_{3}$. Elements such as $\mathrm{Al}, \mathrm{Fe}$ and $\mathrm{Ti}$ had higher concentrations in the coal ashes than in the biomass ashes ${ }^{24}$.

In general, the contents of $\mathrm{CaO}, \mathrm{MgO}, \mathrm{Fe}_{2} \mathrm{O}_{3}, \mathrm{Al}_{2} \mathrm{O}_{3}$ and non-metallic $\mathrm{P}_{2} \mathrm{O}_{5}$ and $\mathrm{SiO}_{2}$ increased with increasing ashing temperature for olive pomace ash and rice husk ash $\left(\text { at } 550^{\circ} \mathrm{C} \text { and } 975^{\circ} \mathrm{C}\right)^{2}, \mathbf{1 1}^{11}$. The greatest difference between the different ashing temperatures for the olive pomace ash was in the content of $\mathrm{K}_{2} \mathrm{O}$, the concentration of which decreased with increasing ashing temperature.

\section{Calculation of the slagging and fouling indexes for the combustion of biomass and coal}

The values of the different indexes are summarized in Tables 6 and 7 and Figs. 4 and 5. The slagging indexes were compared with the ash fusion temperatures.
The lignite ashes show a medium to high tendency for slagging/fouling, except for their $\mathrm{Cl}$ and bed agglomeration indexes. The results of the slagging/fouling indexes are much different for the bituminous coal ashes, as the $\mathrm{Cl}, \mathrm{B} / \mathrm{A}, \mathrm{Rs}, \mathrm{Sr}$ and bed agglomeration indexes show low tendencies for slagging/fouling; on the other hand, the $\mathrm{SiO}_{2}$, silica-alumina ratio, fouling index, iron-calcium ratio, total alkalis and AFI values show medium to high inclinations for slagging/fouling.

In the case of the $\mathrm{SiO}_{2}$ content, hay pellet ash and rice husk ash for all preparation temperatures have a high inclination for slagging. The high levels of silica in the biomass fuels may be caused by contamination with soil or sand ${ }^{7}$.

The $\mathrm{B} / \mathrm{A}$ value is less than 0.5 for the rice husk ash but is significantly higher for the sunflower husk ash. The low $\mathrm{B} / \mathrm{A}$ index for rice husk ash can be attributed to its high $\mathrm{SiO}_{2}$ content, which implies an increased presence of acidic compounds. In general, the $\mathrm{B} / \mathrm{A}$ index of olive

Table 6. Slagging and fouling indexes for selected ashes

\begin{tabular}{|c|c|c|c|c|c|c|c|c|c|c|c|}
\hline $\begin{array}{l}\text { Sample } \\
\text { name }\end{array}$ & $\begin{array}{l}\text { Designation of } \\
\text { ashes }\end{array}$ & $\mathrm{SiO}_{2}[\%]$ & $\begin{array}{c}\text { Silica- } \\
\text { alumina } \\
\text { ratio }[\mathrm{S} / \mathrm{A}]\end{array}$ & $\mathrm{Cl}[\%]$ & $\mathrm{B} / \mathrm{A}$ ratio & Rs index & Fu index & $\begin{array}{c}\mathrm{Sr} \\
\text { index }\end{array}$ & $\begin{array}{l}\text { Iron-calcium } \\
\text { ratio }[/ / C]\end{array}$ & Total alkalis [TA] & $\begin{array}{l}\text { Bed agglomeration index } \\
\text { [BAl] }\end{array}$ \\
\hline $\begin{array}{l}\text { Hay pellet } \\
\text { ash }\end{array}$ & HPA_550 & 50.90 & 24.95 & 0.41 & 0.68 & 0.05 & 14.16 & 85.25 & 0.15 & 20.80 & 0.04 \\
\hline $\begin{array}{c}\text { Corn cob } \\
\text { ash }\end{array}$ & CCA_550 & 11.90 & 10.82 & 4.04 & 3.85 & 0.19 & 141.71 & 56.67 & 0.35 & 36.80 & 0.01 \\
\hline $\begin{array}{c}\text { Olive } \\
\text { pomace ash }\end{array}$ & OPA_550 & 6.93 & 2.63 & 3.50 & 6.17 & 0.67 & 198.62 & 21.99 & 0.09 & 32.20 & 0.05 \\
\hline $\begin{array}{c}\text { Olive } \\
\text { pomace ash }\end{array}$ & OPA_815 & 16.20 & 3.94 & 0.06 & 3.33 & 0.36 & 48.27 & 24.56 & 0.09 & 14.50 & 0.26 \\
\hline $\begin{array}{l}\text { Bituminous } \\
\text { coal ash }\end{array}$ & BCA_815 & 45.60 & 1.64 & 0.02 & 0.24 & 0.14 & 0.73 & 75.37 & 0.91 & 2.99 & 1.98 \\
\hline Lignite ash & LA_815 & 31.70 & 1.43 & 0.01 & 0.52 & 0.73 & 2.13 & 56.22 & 1.83 & 4.10 & 3.46 \\
\hline Lignite ash & LA_975 & 34.30 & 1.39 & 0.02 & 0.51 & 0.71 & 1.97 & 56.31 & 1.76 & 3.89 & 3.83 \\
\hline $\begin{array}{c}\text { Bituminous } \\
\text { coal ash }\end{array}$ & BCA_975 & 44.80 & 1.64 & 0.01 & 0.26 & 0.15 & 0.96 & 75.28 & 0.87 & 3.75 & 1.52 \\
\hline $\begin{array}{c}\text { Olive } \\
\text { pomace ash }\end{array}$ & OPA_975 & 17.10 & 3.95 & 0.01 & 3.21 & 0.34 & 34.67 & 23.84 & 0.09 & 10.80 & 0.38 \\
\hline $\begin{array}{c}\text { Paper } \\
\text { sludge ash }\end{array}$ & PSA_550 & 11.50 & 3.72 & 0.04 & 3.32 & 0.07 & 1.34 & 19.21 & 0.01 & 0.40 & 0.99 \\
\hline $\begin{array}{l}\text { Sunflower } \\
\text { husk ash }\end{array}$ & SHA_550 & 0.16 & 0.21 & 1.33 & 68.18 & 10.03 & 2454.41 & 0.68 & 0.01 & 36.00 & 0.003 \\
\hline $\begin{array}{l}\text { Rice husk } \\
\text { ash }\end{array}$ & RHA_550 & 91.60 & 654.29 & 0.10 & 0.06 & 0.003 & 0.21 & 98.74 & 0.06 & 3.65 & 0.01 \\
\hline $\begin{array}{l}\text { Rice husk } \\
\text { ash }\end{array}$ & RHA_815 & 94.50 & 794.12 & 0.01 & 0.04 & 0.002 & 0.12 & 99.13 & 0.07 & 2.83 & 0.02 \\
\hline $\begin{array}{l}\text { Rice husk } \\
\text { ash }\end{array}$ & RHA_975 & 93.30 & 405.65 & $<0.01$ & 0.05 & 0.002 & 0.12 & 98.63 & 0.08 & 2.52 & 0.03 \\
\hline & $\begin{array}{l}\text { Extremely high } \\
\text { High } \\
\text { Medium } \\
\text { Low }\end{array}$ & & & & & & & & & & \\
\hline
\end{tabular}

Table 7. Ash fusibility index (AFI) and deformation temperature (DT) for selected ashes

\begin{tabular}{|c|c|c|c|c|c|}
\hline Sample name & Designation of ashes & $\begin{array}{c}\mathrm{AFI}\left[{ }^{\circ} \mathrm{C}\right] \text { - oxidation } \\
\text { atm. }\end{array}$ & $\begin{array}{c}\mathrm{AFI}\left[{ }^{\circ} \mathrm{C}\right]-\text { reduction } \\
\text { atm. }\end{array}$ & $\begin{array}{c}\mathrm{DT}\left[{ }^{\circ} \mathrm{C}\right] \text { - oxidation } \\
\text { atm. }\end{array}$ & $\begin{array}{c}\mathrm{DT}\left[{ }^{\circ} \mathrm{C}\right] \text { - reduction } \\
\text { atm. }\end{array}$ \\
\hline Hay pellet ash & HPA_550 & 926 & 904 & 880 & 840 \\
\hline Corn cob ash & CCA_550 & 982 & 898 & 970 & 880 \\
\hline Olive pomace ash & OPA_815 & 1252 & 1290 & 1240 & 1270 \\
\hline $\begin{array}{l}\text { Bituminous coal } \\
\text { ash }\end{array}$ & BCA_815 & 1308 & 1284 & 1300 & 1270 \\
\hline Lignite ash & LA_815 & 1314 & 1212 & 1310 & 1190 \\
\hline Lignite ash & LA_975 & 1314 & 1202 & 1310 & 1190 \\
\hline $\begin{array}{l}\text { Bituminous coal } \\
\text { ash }\end{array}$ & BCA_975 & 1316 & 1280 & 1310 & 1270 \\
\hline Olive pomace ash & OPA_975 & $>1500$ & 1296 & $>1500$ & 1280 \\
\hline Paper sludge ash & PSA_550 & $>1500$ & $>1500$ & $>1500$ & $>1500$ \\
\hline $\begin{array}{l}\text { Sunflower husk } \\
\text { ash }\end{array}$ & SHA_550 & $>1500$ & $>1500$ & $>1500$ & $>1500$ \\
\hline Rice husk ash & RHA_550 & $>1500$ & $>1500$ & $>1500$ & $>1500$ \\
\hline Rice husk ash & RHA_975 & $>1500$ & $>1500$ & $>1500$ & $>1500$ \\
\hline & \multicolumn{5}{|l|}{$\begin{array}{l}\text { High } \\
\text { Medium } \\
\text { Low }\end{array}$} \\
\hline
\end{tabular}




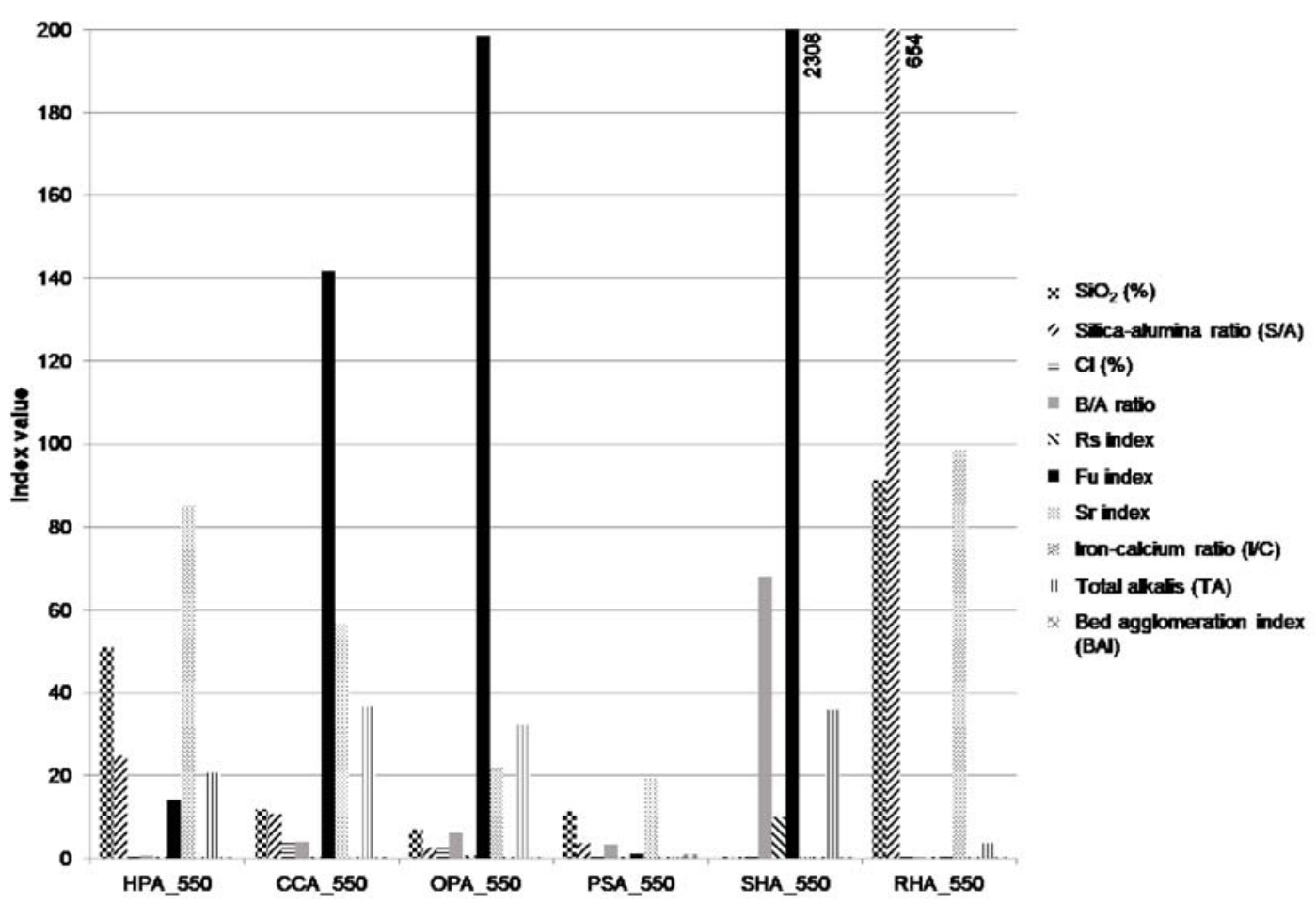

Figure 4. Slagging and fouling indexes for biomass ashes prepared at $550^{\circ} \mathrm{C}$

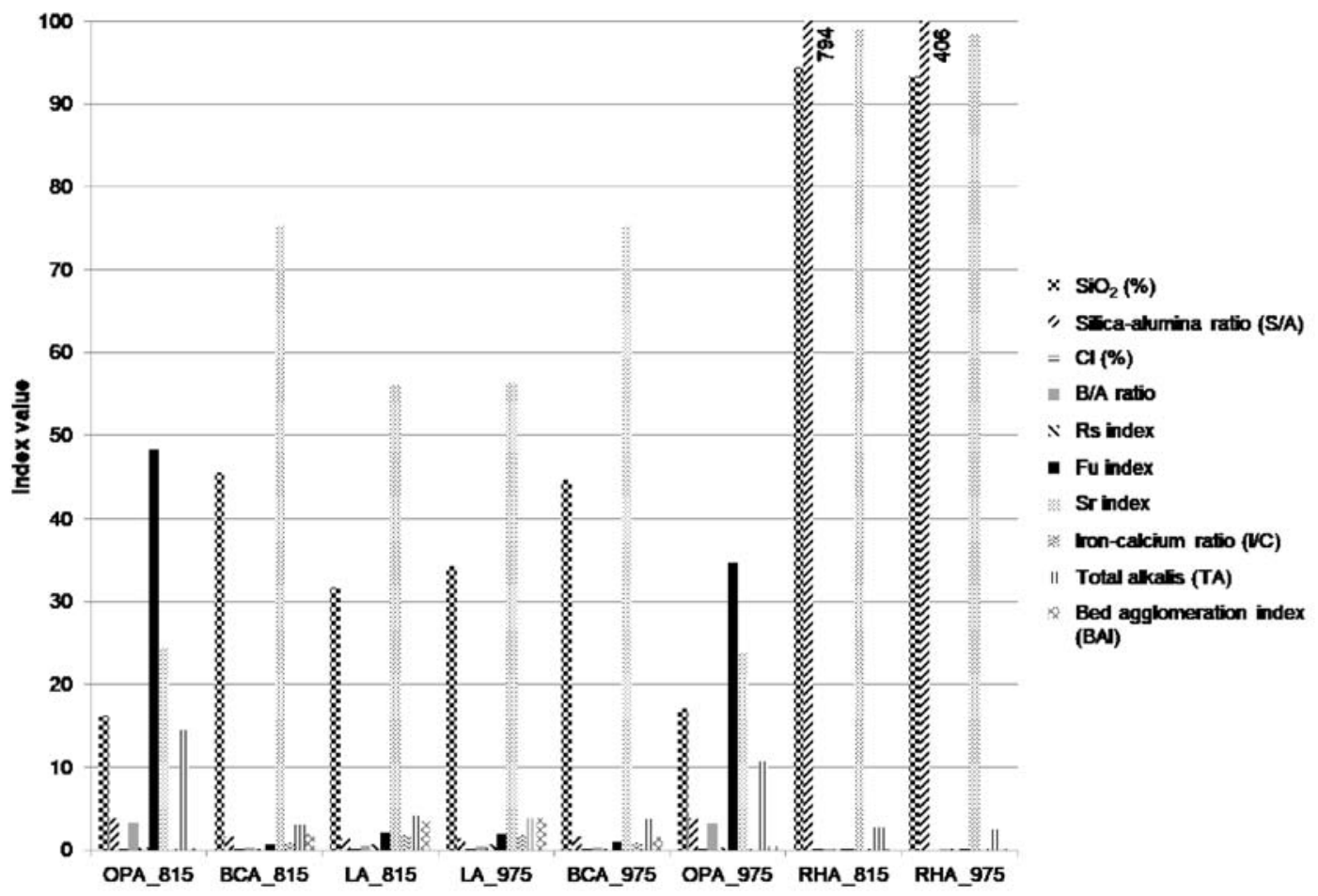

Figure 5. Slagging and fouling indexes for biomass and coal ashes prepared at $815^{\circ} \mathrm{C}$ and $975^{\circ} \mathrm{C}$

pomace ash and rice husk ash decreased with increasing ashing temperature, meaning there are more acidic oxides and less basic oxides in these ashes. The calculation of the Rs index is derived from the $\mathrm{B} / \mathrm{A}$ index, which is extremely high for sunflower husk ash and mid-range for olive pomace ash prepared at $550^{\circ} \mathrm{C}$.

The slagging probabilities were high for ashes prepared from paper sludge, corn cobs, sunflower husks and olive pomace according to their $\mathrm{Sr}$ ratios, which were lower than 65 .

The slagging tendency based on the silica-alumina ratio was high for the ash prepared from olive pomace at $550^{\circ} \mathrm{C}$. The slagging tendency based on the iron-calcium ratio was high for corn cob ash.

The ash fusibility index (AFI) was extremely high for hay pellet ash and corn cob ash under oxidative and reductive atmospheres. A low AFI was calculated for olive pomace ash prepared at $975^{\circ} \mathrm{C}$, paper sludge ash, sunflower husk ash and rice husk ash. The remaining ashes had mid-range values of AFI.

According to the chloride content, extremely high fouling inclinations were seen for corn cob ash, sunflower husk ash and olive pomace ash prepared at $550^{\circ} \mathrm{C}$, and a high fouling inclination was seen for hay pellet ash. 
The value of the Fu fouling index of rice husk ash is less than 0.6. Thus, there is only a low probability of fouling. In the case of paper sludge ash, hay pellet ash and olive pomace ash prepared at $975^{\circ} \mathrm{C}$, their fouling index values are in the range of $0.6-40$; therefore, they have a mid-range probability of fouling. Ashes from olive pomace prepared at $550^{\circ} \mathrm{C}$ and $815^{\circ} \mathrm{C}$, corn cobs and sunflower husks have fouling index values over 40 , indicating that their probabilities of fouling are high. The fouling tendency based on total alkalis was high for all types of ash.

The results show that the ashing temperature of rice husks did not have a significant influence on its index values.

The calculated slagging indexes did not always match the results of the fusion temperatures of the ashes listed in Table 3. For example, the ash fusion temperatures for sunflower husk ash is $>1500^{\circ} \mathrm{C}$, while the values of $\mathrm{B} / \mathrm{A}$ index, Rs index, $\mathrm{Sr}$ index, and bed agglomeration index indicate a high or extremely high tendency for slagging. Based on practical applications, ashes prepared from the combustion of sunflower husks lead to slagging in boilers; therefore, their ash fusion temperatures should be lower. On the other hand, good agreement of the fusion temperature (DT) with the slagging indexes is seen in the case of corn cob ash, for which the B/A index, $\mathrm{Sr}$ index, iron-calcium ratio, bed agglomeration index and AFI are in the range of high or extremely high. Additionally, for rice husk ash, when the fusion temperatures are $>1500^{\circ} \mathrm{C}$, the slagging index values are low except for those of $\mathrm{SiO}_{2}$ and the bed agglomeration index, which are high.

\section{SUMMARY}

Ashes were prepared by annealing selected types of solid fuels (biomass, coal, and alternative fuels) at different temperatures $\left(550^{\circ} \mathrm{C}, 815^{\circ} \mathrm{C}\right.$ and $\left.975^{\circ} \mathrm{C}\right)$. Ash fusion temperatures were measured by a LECO AF-700 instrument. The lowest deformation temperature (below $1000^{\circ} \mathrm{C}$ ) was seen for the ashes prepared from hay pellets and corn cobs. On the other hand, the deformation temperature exceeded $1500^{\circ} \mathrm{C}$ for ashes made from paper sludge, sunflower husks and rice husks.

The effects of the major element and chloride concentrations on the melting temperatures of the ashes were compared. $\mathrm{SiO}_{2}, \mathrm{Al}_{2} \mathrm{O}_{3}$ and $\mathrm{CaO}$ may increase the melting point in the case of paper sludge ash and olive pomace ash. High amounts of $\mathrm{P}_{2} \mathrm{O}_{5}, \mathrm{Na}_{2} \mathrm{O}$ and $\mathrm{K}_{2} \mathrm{O}$ may decrease the melting point of corn cob ash. Ashes prepared from corn cobs and sunflower husks can easily be sintered due to high amounts of potassium. A low melting temperature was seen only for the corn cob ash, which is consistent with its high potassium content. In contrast, paper sludge ash and rice husk ash, which had low potassium contents, have high melting temperatures. The corn cob ash has a higher content of chlorine than the other ashes, which can be harmful because of the corrosion risk. Increased ashing temperature resulted in an increase in the $\mathrm{CaO}, \mathrm{MgO}, \mathrm{Fe}_{2} \mathrm{O}_{3}, \mathrm{Al}_{2} \mathrm{O}_{3}$ and nonmetallic $\mathrm{P}_{2} \mathrm{O}_{5}$ and $\mathrm{SiO}_{2}$ contents in olive pomace ash and rice husk ash (prepared at $550^{\circ} \mathrm{C}$ and $975^{\circ} \mathrm{C}$ ).
Slagging and fouling properties were investigated by calculating the slagging and fouling indexes. The calculated slagging indexes did not always agree with the results of the ash fusion temperatures. For example, the deformation temperature for sunflower husk ash was $>$ $1500^{\circ} \mathrm{C}$, while the values of the $\mathrm{B} / \mathrm{A}$ ratio, $\mathrm{Rs}$ index, $\mathrm{Sr}$ index, and bed agglomeration index resulted in a high tendency for slagging.

In conclusion, the use of calculated indexes for biomass ashes is limited. Therefore, new indexes should be created from real-world combustion results and be determined based on the combustion device, and conditions as well as the physicochemical characterization of the biomass fuels and their ashes.

\section{ACKNOWLEDGEMENT}

The presented work was financially supported by the project "Innovation for Efficiency and Environment - Growth", identification code LO1403 with financial support from the Ministry of Education, the Youth and Sports in the framework of the National Sustainability Programme by ERDF/ESF „Research on the identification of combustion of unsuitable fuels and systems of self-diagnostics of boilers combustion solid fuels for domestic heating“, No. CZ.02.1.01/0.0/0.0/18_069/0010049 and by the project SP2018/102 "Identification of incineration of unsuitable fuels in domestic heating, usability of catalysts to reduce pollutant emissions".

\section{LITERATURE}

1. Romero, E., Quirantes, M. \& Nogales, R. (2017). Characterization of biomass ashes produced at different temperatures from olive-oil-industry and greenhouse vegetable wastes. Fuel. 208, 1-9. DOI: doi.org/10.1016/j.fuel.2017.06.133.

2. Niu, Y., Tan, H., Wang, X., Liu, Z., Liu, H., Liu, Y. \& Xu, T. (2010). Study on fusion characteristics of biomass ash. Bioresource Technol. 101 (23), 9373-9381. DOI: doi.org/10.1016/j.biortech.2010.06.144.

3. Fang, X., Jia, L., Wang, F. \& Yu, G. (2012). Experimental study on ash fusion characteristics of biomass. Bioresource Technol. 104(1), 769-774. DOI: doi.org/10.1016/j. biortech.2011.11.055.

4. Xiao, R., Xueli, C., Fuchen, W. \& Guangsuo, Y. (2011). The physicochemical properties of different biomass ashes at different ashing temperature. Renew. Energ. 36(1), 244-249. DOI: doi.org/10.1016/j.renene.2010.06.027.

5. Malat'ák, J. \& Vaculík, P. (2008). Biomasa pro výrobu energie. Praha, Česká zemědělská univerzita v Praze. ISBN 978-80-213-1810-6.

6. Holubcik, M. \& Jandacka, J. (2014). Mathematical model for prediction of biomass ash melting temperature using additives. Komunikacie. 16 (3A), 48-53. ISSN:1335-4205.

7. Garcia-Maraver, A., Mata-Sanchez, J., Carpio, M. \& Perez-Jimenez, J.A. (2017). Critical review of predictive coefficients for biomass ash deposition tendency. J. Energy Inst. 90, 214-228. DOI: doi.org/10.1016/j.joei.2016.02.002.

8. Vamvuka, D. \& Kakaras, E. (2011). Ash properties and environmental impact of various biomass and coal fuels and their blends. Fuel Process Technol. 92, 570-581. DOI: doi. org/10.1016/j.fuproc.2010.11.013.

9. Pronobis, M., Kalisz, S. \& Polok, M. (2013). The impact of coal characteristics on the fouling of stoker-fired boiler convection surfaces. Fuel. 112, 473-482. DOI: doi.org/10.1016/j. fuel.2013.05.044. 
10. Yao, X., Xu, K., Yan, F. \& Yu, L. (2017). The influence of ashing temperature on ash fouling and slagging characteristics during combustion of biomass fuels. Bioresources. 12(1), 1593-1610.

11. Du, S., Yang, H., Qian, K., Wang, X. \& Chen, H. (2014). Fusion and transformation properties of the inorganic components in biomass ashes. Fuel. 117, 1281-1287. DOI: doi. org/10.1016/j.fuel.2013.07.085.

12. Fernandes, I.J., Calheiro, D., Kieling, A.G., Moraes, C.A.M., Rocha, T.L.A.C., Brehm, F.A. \& Modolo, R.C.E. (2016). Characterization of rice husk ash produced using different biomass combustion techniques for energy. Fuel. 165, 351-359. DOI: doi.org/10.1016/j.fuel.2015.10.086.

13. Li, W., Li, Q., Zhang, Y. \& Meng, A. (2012). Ashing temperature's impact on the characteristics of biomass ash. Appl. Mech. Mater. 260-261, 217-223. DOI: doi.org/10.4028/ www.scientific.net/AMM.260-261.217.

14. Yao, X., Xu, K. \& Li, Y. (2017). Experimental investigation of performance properties and agglomeration behavior of fly ash from gasification of corncobs. J. Cent. South. Univ. 24, 496-505. DOI: doi.org/10.1007/s11771-017-3452-6.

15. Yao, X., Xu, K. \& Yan, F. (2016). Comparative study of characterization and utilization of corncob ashes from gasification process and combustion process. Constr. Build. Mater. 119, 215-222. DOI: doi.org/10.1016/j.conbuildmat.2016.04.077.

16. Rizvi, T., Xing, P., Pourkashanian, M., Darvell, L.I., Jones, J.M. \& Nimmo, W. (2015). Prediction of biomass ash fusion behaviour by the use of detailed characterisation methods coupled with thermodynamic analysis. Fuel. 141, 275-284. DOI: doi.org/10.1016/j.fuel.2014.10.021.

17. Suárez-García, F., Martínez-Alonso, A., Llorente, F.M. \& Tascón, J.M.D. (2002). Inorganic matter characterization in vegetable biomass feedstocks. Fuel. 81, 1161-1169. DOI: doi. org/10.1016/S0016-2361(02)00026-1.

18. International Organization for Standardization. (2016). Solid biofuels - Determination of ash content. ISO 18122:2015.

19. International Organization for Standardization. (2010). Solid mineral fuels - Determination of ash. ISO 1171:2010.

20. Česká technická norma (2013). Method of testing cement - Part 2: Chemical analysis of cement. ČSN EN 196-2:2013.

21. žProg. Energy Combust. Sci. Ash-related issues during biomass combustion: Alkali-induced slagging, silicate meltinduced slagging (ash fusion), agglomeration, corrosion, ash utilization, and related countermeasures. 52, 1-61. DOI: doi. org/10.1016/j.pecs.2015.09.003.

22. International Organization for Standardization. (2008). Hard coal and coke - Determination of ash fusibility. ISO 540:2008.

23. European Committee for Standardization. (2007). Solid biofuels - Method for the determination of ash melting behavior - Part 1: Characteristic temperatures method. CEN/TS 15370-1.

24. Vassilev, S.V., Vassileva, C.G., Song, Y.C., Li, W.Y. \& Feng, J. (2017). Ash contents and ash-forming elements of biomass and their significance for solid biofuel combustion. Fuel. 208, 377-409. DOI: doi.org/10.1016/j.fuel.2017.07.036.

25. Liu, B., He, Q., Jiang, Z., Xu, R. \& Hu, B. (2013). Relationship between coal ash composition and ash fusion temperatures. Fuel. 105, 293-300. DOI: doi.org/10.1016/j. fuel.2012.06.046.

26. Magdziarz, A., Dalai, A.K. \& Kozinski, J.A. (2016). Chemical composition, character and reactivity of renewable fuel ashes. Fuel. 176, 135-145. DOI: doi.org/10.1016/j. fuel.2016.02.069.

27. Reinmoller, M., Schreiner, M., Guhl, S., Neuroth, M. \& Meyer, B. (2017). Formation and transformation of mineral phases in various fuels studied by different ashing methods. Fuel. 202, 641-649. 